TEME, г. XLIV, бр. 1, јануар - март 2020, стр. 83-94

Прегледни рад

Примљено: 9. 12. 2019.

https://doi.org/10.22190/TEME191209010V

Ревидирана верзија: 10. 2. 2020

UDK 347.637:347.9

Одобрено за штампу: 20. 2. 2020.

\title{
THE POSITION OF THE CHILD IN LITIGATION PROCEEDINGS IN THE LEGAL MATTERS OF EXERCISE, DEPRIVATION AND RESTORATION OF PARENTAL RIGHTS
}

\author{
Ranka Vujović \\ The Republic Secretariat for Legislation of the Government \\ of the Republic of Serbia, Belgrade, Serbia \\ ranka.vujovic@gov.rs
}

\begin{abstract}
Numerous entities in various procedural roles participate in the litigation proceedings for the exercising, denying and restoring of parental rights. The usual classification of litigation participants into subjects in a narrow, and subjects in a broader sense, may apply to such litigations. In the narrow sense, the subjects of the litigations are the litigation court and the litigants. In a broader sense, these are all persons who in any way participate in the litigation: interveners, counsel, witnesses, expert witnesses, interpreters, translators. Some of them participate in the proceedings to protect their own, and others to protect the rights and interests of others, and some are there to provide the necessary assistance in collecting the litigation material, present evidence, etc. Pursuant to the family laws, the capacity of a party in these proceedings, through the standardization of the right to the standing to commence an action, is assigned to the child, parents, custody authority and the public prosecutor. However, these are only potential, but not necessary participants in these proceedings. The proceedings may also be initiated and conducted without all the participants of the family-legal relation participating in them. As a rule, there is no participation of the child as a party, although, essentially, the child's right to live with parents and to have (adequate) parental care is the central theme of the proceedings. In all of these litigations, in fact, legal protection is afforded to the rights of the child arising from the parent-child relationship, namely from the rights and duties of the parent towards the child. This paper critically analyzes the national regulations governing the position of the child in litigation proceedings in the legal matters of exercising, denying and the restoring of parental rights, with a view to determine whether, and to what extent, the solutions contained in those regulations comply with the postulates of a fair trial, enable the exercise of a child's right to participate in the proceedings that are to decide on the issues that affect him/her and provide effective protection of his/her procedural rights.
\end{abstract}

Key words: child, court, litigation, exercise, deprivation and restoration of parental rights. 


\title{
ПОЛОЖАЈ ДЕТЕТА У СУДСКОМ ПАРНИЧНОМ ПОСТУПКУ У ПРАВНИМ СТВАРИМА ВРШЕЫА, ЛИШЕЊА И ВРАһАЊА РОДИТЕЉСКОГ ПРАВА
}

\begin{abstract}
Апстракт
У поступку у парницама за вршење, лишење и враћање родитељског права учествују бројни субјекти у различитим процесним улогама. Уобичајена класификација учесника парничног поступка на субјекте у ужем и ширем смислу може се применити и на ове парнице. У ужем смислу, субјекти тог поступка јесу парнични суд и парничне странке. У ширем смислу, то су сва она лица која на било који начин суделују у парничном поступку: умешачи, заступници, сведоци, вештаци, тумачи, преводиоци. Неки од њих учествују у поступку да би штитили сопствена права и интереce, неки да би штитили туђа права и интересе, а неки су ту да би пружили неопходну помоћ суду у прикупљању процесне грађе, извођењу доказа и сл. Породичним законом је својство странке у тим поступцима, кроз нормирање активне легитимације, додељено детету, родитељима, органу старатељства и јавном тужиоцу. Међутим, ово су само потенцијални, али не и нужни, учесници у тим поступцима. Поступак се може и покренути и водити, а да у њему не учествују сви учесници спорног породичноправног односа. По правилу, изостаје учешће детета као странке, иако је, суштински, централна тема поступка право детета на живот са родитељима и на (адекватно) родитељско старање. У свим овим парницама, заправо, правна заштита пружа се правима детета која произлазе из родитељско-дечјег односа, односно из права и дужности родитеља према детету. У овом раду критички се анализирају национални прописи који уређују положај детета у судском парничном поступку у правним стварима вршења, лишења и враћања родитељског права, с циљем да се утврди да ли и у којој мери решења садржана у тим прописима прате постулате правичног суђења, омогућавају остваривање права детета да суделује у поступцима у којима се одлучује о питањима која га се тичу и обезбеђују делотворну заштиту његових процесних права.
\end{abstract}

Кључне речи: дете, суд, парница, вршење, лишење и враћање родитељског права.

\section{INTRODUCTION}

The civil proceedings are based on the two-party structure and can only be maintained as long as the two-party structure exists. The twoparty nature of the proceedings corresponds to the existence of the two special interests of the parties, which are opposed to each other in the dispute (Poznić, Rakić-Vodinelić, 2015, pp. 186-187). The parties to civil proceedings are, in material terms, the subjects of the substantive legal relationship in which the dispute arises (the titles of subjective law, the holders of rights and obligations). Procedurally, the parties are the plaintiff - the person who seeks legal protection of his/her right by filing the claim, and the defendant - the person against whom the claim is filed, i.e. against whom legal protection is sought. In principle, this rule also applies to the specific civil proceedings relating to family relations, such as those in proceedings for the exercise, deprivation and restoration of parental rights. The Family Law defines special rules that apply to all 
proceedings related to family relations, as well as special, common procedural rules for deciding on the issues of exercising, depriving and restoring parental rights (and on the protection of the rights of the child) to which the title of Section 4, Chapter I of Part 10 of the Family Law of the Family Law refers: Procedure in the dispute for the protection of the rights of the child and dispute for the exercise and deprivation of parental rights. In this paper, we will limit ourselves to the issues of the procedural position of a child in civil proceedings in legal matters related to family relationships, which relate to the status issues of exercising, depriving and restoring parental rights.

The legal standing and status of the parties in civil proceedings for the exercise, deprivation and restoration of parental rights are governed by two systemic laws - the Law on Civil Procedure (hereinafter referred to as the LCP), which contains the rules of general civil proceedings, and the Family Law, which contains specific rules applicable to family relations proceedings. The procedures in litigation for the exercise, deprivation and restoration of parental rights are subject to the same procedural rules. The circle of persons with legal standing to sue is somewhat different, but what they have in common is that in all three cases the child has the secured place as the plaintiff. ${ }^{1}$

With respect to the existence of the party, the rules of the general civil procedure apply. The parties are determined in the claim. Entities acquire the capacity of a party at the time of filing the claim as a litigation action that initiates civil proceedings, but the status of a party can also be acquired subsequently, by the succession in a procedural relationship (in case of subjective reversal of the claim, the intervener coming to the place of the party that it joined, etc.). The party should exist at the time of the filing the claim, as well as during the course of the proceedings.

The participation of parties in civil proceedings is a necessity and one of the basic principles of civil proceedings, because it is through their actions that factual material is obtained that will serve as the basis for making a correct and lawful decision. Such a decision, proper and lawful, requires that all parties in the dispute be heard-audiatur et altera pars. In addition to the participation of the parties, the need for full and proper clarification of the disputed case often imposes the need for the participation of third parties who can contribute to the establishment of material truth (such as witnesses, expert witnesses, etc.). While, in the

\footnotetext{
${ }^{1}$ A lawsuit for exercising parental rights may be filed by: a child, parents and guardian (Family Law, Article 264, paragraph 1), a lawsuit for deprivation of parental rights may be filed by: child, the other parent, public prosecutor and guardian (Family Law, Article 264, paragraph 2), while lawsuit for restoration of parental right, in addition to persons who can claim deprivation of parental right, may also be filed by the parent who was deprived of parental right (Family Law, Article 264, paragraph 3).
} 
case of witnesses or expert witnesses the law leaves it to the court to determine whether in a particular case there is a need for their participation and to what extent, the need for the parties to participate in the proceedings, given their particular position, is a necessity.

In lawsuits for the exercise, deprivation and restoration of parental rights, the participation of all participants in that family relationship - the parent-child relationship, is invaluable in order to correctly and fully establish the facts and make a decision that will protect the interests of the child as much as possible. Nonetheless, the child's participation in court proceedings and, in general, their right to participate in the making of all the decisions significant for them has been challenged at both the theoretical and practical (implementation) level, more than any other convention law (Vučković Šahović, Petrušić, 2015, pp. 105, 106). Although the Convention on the Rights of the Child (hereinafter the: CRC) raised this right of the child to the level of a basic principle, the fact that it significantly influences the change of the deeply rooted image of the child in society and the relationship between adults and children, traditionally based on power relations, influenced that this social construct and its transposition into the legal framework has been approached very cautiously.

The conventionally promoted principle of participation long after its ratification (CRC was ratified in 1990) was not applied in practice, although there were no formal obstacles, given the applicable constitutional solutions regarding the hierarchy of regulations and the possibility of direct application of international legal acts. Only after its transposition into national regulations, in 2005, by adopting the Family Law, it formally changed the position of the child, transforming it from an object enjoying protection (of adults and institutions) into the subject of family (parentchild) relationships, thus allowing the child to not only to be an active participant in their own growing up, but also to take an active part in all the proceedings in which his/her rights are decided, including those before the court. In this way, a new social construct in the understanding of the concept of childhood also received its legal verification.

\section{LITIGATION CAPACITY, REPRESENTATION AND SECURING THE CHILD'S PARTICIPATION IN LAWSUITS FOR EXERCISING, DEPRIVING AND RESTORING PARENTAL RIGHTS}

The contemporary concept of justice that adapts in all its elements to the needs of children - child-friendly justice - is a new concept of justice that ensures that in every proceeding all the rights of the child are respected, including the right of the child to be informed, to have legal representative, to take an active part in the proceedings and to be protected (Petrušić, 2016, pp. 395). These standards are based on the postulates of a fair trial, and their implementation implies the full application of the rule of law principle. 
In our family procedural legislation, the procedural-legal position of a child in court proceedings relating to his/her family rights is defined by prescribing special rules of court procedure, different from those applicable in other civil court proceedings, and by recognizing the child's specific procedural abilities.

In lawsuits for the exercise, deprivation and restoration of parental rights, the child has the right to sue, i.e. its capacity to sue (ius standi in iudicio) is recognized. The capacity to become a party in the litigation is a prerequisite for the existence of the capacity to independently undertake litigation actions, because only the persons who have the capacity to become parties in litigation also have the capacity to litigate (Dika, 2008, pp. 13-17). The capacity to be a party, as a rule, allows the parties to personally take legal actions before the court, with a procedural-legal effect (postulatory capacity) or to authorize a proxy for this. The postulation inability is a procedural impediment. Since only a party with the legal capacity can take actions in the proceedings independently, and a child until the age of 14 is has no capacity to conduct business (Family Law, Article 64), they must be represented in court proceedings. Older minors (children aged 14 or over) have partial legal capacity. According to the Family Law, they can undertake all legal transactions with the prior or subsequent consent of the parents (except for the disposal of property, for which they need the consent of the guardian). Children over the age of 15 , if they are able to reason, make their own decisions about which parent they will live with (Family Law, Article 60, paragraph 4), or whether and how to maintain personal relationships with the parent with whom they do not live (Family Law, Article 61, paragraph 4). As a child has the capacity to litigate within the limits of his/her recognized legal capacity (LCP, Article 75), they may legally take all procedural actions within the limits of their procedural capacity "because the capacity to litigate is always complete" (Stanković, 2009, 115).

The same rule should apply to the issuance of powers of attorney - the extent of a child's legal capacity in a particular case should determine whether they can authorize another person to represent them. A child could authorize a person to represent him or her only in the case of undertaking legal activities that the child could legally undertake:

"What cannot be owned by law cannot be acquired through another" (Stanković, Vodinelić, 1996, pp. 201).

The Family Law recognizes the right and duty of parents to represent the child not only in all legal affairs and in all proceedings beyond the child's legal and procedural capacity (legal representation), but they also have the right and duty to represent the child in all legal affairs and in all proceedings within the limits the child's legal and procedural abilities (voluntary representation), which particularly challenges the child's postulatory capacity.

That solution, according to which "parents have the right and the duty to represent the child in all legal affairs and in all proceedings within 
the limits of the child's legal capacity and procedural capacity, unless otherwise provided by law (voluntary representation)" (Family Law, Article 72, paragraphs 1 and 2) is the original solution in our family law and raises a number of questions in its application. Until now, it has been clear in legal theory that, unlike statutory representation, which implies that it is such an authorization for the representation against which the represented person has no influence, for voluntary representation it is decisive, since it has its basis in the will of the person represented and assumes their determination to be represented by an attorney (Rosenberg, 1954, § 47 I 1). However, because of the deviation from the usual understanding of the term voluntary representation, this domestic solution faces different interpretations by legal theorists. While some consider it to be a "legally voluntary" representation because the basis of the power of attorney is not the will of the child, but the law itself (Petrušić, 2018, 175), others believe that it is basically still a matter of legal representation regardless of the child's business and litigation capacity and that the child's "will" is practically reflected in their tacit consent to parental representation (Palačković, 2006, 363). There are also such legal authors who believe that voluntary representation can by no means be legal because it is the basis for the child's voluntary representation, his/her will (Draškić, 2005, pp. 287; Kovaček Stanić, 2005, pp. 288).

If one accepts the (logical) view that the basis for the child's voluntary representation in litigation is his/her will, then, taking into account the given legal definition of voluntary representation, a new question arises, namely the question of how that child's will is expressed. Is it in a situation where the child has a special business and process, i.e. litigation capacity, that his/her tacit consent to parental representation in court proceedings is sufficient, or his/her will to be represented by his/her parents must be formalized through a certified written or record statement or power of attorney? If the said standard were not to be understood as the right of the child to decide to be represented through the parent in a particular proceeding, then his/her legally recognized special legal capacity would be completely devalued. Why the recognition of a child's special legal capacity, if the parent can always decide that he/she will represent the child, and not the child him/herself? When the child in the specific case has the legal capacity, and when it has full litigation capacity, the duty of the parent to represent him/her exists only if the child asks for this from the parent and duly authorizes them. In this case, the parent cannot have his/her own right to represent the child that has litigation capacity - the right of representation can only arise from the will of the child expressed through the power of attorney that the child, as the principal, has given him/her. Conversely, the parent has a duty to accept representation if the child requires it (the child as the principal can also chose to be represented by a lawyer, because he/she is the holder of the authority and the holder of the specific right he/she protects). The legal definition itself raises the question of the possibility of termination of power of attorney, given the duty of the 
parent to accept to represent the child. Given the standards of justice that respect the rights of the child, the child should have the right to revoke that power of attorney at any time.

The next question raised by thus defined voluntary representation is the question of the extent of the power of representation. Starting from the view that the child has litigation capacity within the limits of his/her (special) legal capacity, the question arises as to whether the authorizations of a parent as a willing representative of the child are adapted to the powers of the legal representative, since the parents are the representatives of the child by law or are adapted to the powers of a proxy. Does the child have the right to determine the extent of the power of representation? There is also the question of the child's right to decide whether he/she will be represented by both parents or by one parent as willing counsel. The problem can also arise if there are conflicts between the actions taken by the child and the actions taken by the parent. Is the parent responsible for the damage caused to the child by incorrect representation? Does the court have the duty to appoint the child's temporary representative if he/she finds that he/she is inadequately represented in the proceedings (Family Law, Article 266, paragraph 2) even when the child has special legal capacity and full litigation capacity? Can the court appoint a temporary representative at all to a child who has legal and litigation capacity without his/her consent, i.e. request (Family Law, Article 265, paragraph 3)? The questions are numerous and require immediate resolution, as improper representation is a material breach of the provisions of the civil procedure, which pays attention to by both the second instance and the revision court ex officio (LCP, Article 374, paragraph 2, clause 9).

But let us get back to the legal representation of a child. As already mentioned, in lawsuits for the exercise, deprivation and restoration of parental rights the child has the capacity to bring proceedings as the holder of rights from family relations, therefore they have the position of an authorized plaintiff. However, in terms of the capacity to stand trial (and the defendant has the capacity to stand trial if the corresponding duty is related to him/her), things are a little different. Namely, it may be concluded from the accepted concept of the subjective family rights of the child as human rights and the accepted definition of parental right as the parental duty, which they carry out "only to the extent necessary to protect the person, rights and interests of the child," that the child does not have the capacity to be sued, namely he/she does not have the position of a necessary and unique co-litigant with the parents in the proceedings in which it is decided on the exercising, deprivation or restoration of parental rights. The actual capacity to stand trial in these proceedings belongs to the parents, regardless of the capacity of the child, although, due to the nature of the legal relationship, according to the general rules of civil procedure law, the claim should include all persons who are parties to that material 
legal relationship (Petrušić, 2006a, 183). In family-law disputes where the court is obliged to decide in its ruling, in addition to the main issue which is the subject of the lawsuit, also on exercising, and may also decide on the deprivation of parental rights (such as marital disputes, Family Law, Article 226) - the child does not have the position of a litigant. Generally, in domestic law, except in maternity and paternity disputes, the child is not provided with the position of a litigant in litigations in which the litigation for exercising and the litigation for the deprivation of parental rights are conducted at the same time. In such a situation, in a litigation based on the two-party structure, the procedural position of the child is "blurred" because the child is only a "hidden", "covert" party (Stanković, 2012, pp. 42), although the child is a necessary participant in the substantive legal relationship considered by the court and whatever decision it makes, it will affect the position and rights of the child in the parent-child relationship.

In a lawsuit for the exercise, deprivation or restoration of parental rights, in which the child has not acquired the status of a party, the child could, as an independent holder of rights from family relations, acquire the position of an intervener under the general rules of civil procedure law (LCP, Article 215), namely the intervener with the position of unique colitigant (because the effect of the ruling also applies to the child). Although this legal possibility exists as a general procedural rule, it is practically inapplicable, since the Family Law did not pay special attention to this issue. Without proper procedural operationalization, the law itself, even though legally proclaimed, and albeit the supreme convention principle (participation), is not possible without a closer provision that would define who is obliged to inform the child of the possibility of participating as a court intervener in the proceedings in which issues important for him/her are being decided upon, and, additionally, who is responsible to prepare the child for such participation.

Similar issues are related to other aspects of the child's participation in court proceedings. If a child participates in the proceedings as a witness, he/she is subject to the same procedural rules that were prescribed for witnesses in general civil proceedings - there are no adjusted rules on how to prepare a child for testimony, on the manner of hearing, nor are there provisions on the witness failure to respond to subpoena, on the contempt of court, etc., and these are all appropriate to situations involving a child as a witness (Vujović, 2019, 199).

Although the applicable legal regulations generally proclaim the right of a child to be a party even when he/she is not a party, he/she has the right to express his/her opinion freely and directly in any proceedings in which his/her rights are decided (Family Law, Article 65), the procedural legislation does not provide the mechanisms for exercising that right of the child. The court, as well as the collision guardian, or the child's temporary representative, has a duty to allow the child to express his/her opinion 
freely - but only when the child is a party (Family Law, Articles 265 and 266) (Ćorac, 2014, 331). In addition, the provisions on the exercise of the child's right to express an opinion require special analysis. It is undisputed in legal theory that the full participation of the child in the proceedings is not ensured by the mere "hearing" of the child who is able to express his/her opinion, but rather that it is a complex process that involves multiple stages. In this respect, the domestic legislator also stipulated that the court in a lawsuit first determines whether a child is capable of forming his/her opinion, taking into account the child's age, developmental abilities, etc. In this process, the court, as a rule, consults experts. If the court determines that the child is capable of forming his/her opinion, it must: 1) ensure that the child receives all the information he/she needs to express his/her opinion in due time; 2) allow the child to express his/her opinion directly; 3) make sure that the consequences of accepting this opinion are appropriately explained to the child: 4) determine the child's opinion in a manner and place appropriate to them, and his/her maturity; 5) give due consideration to the child's opinion. The assessment of whether the child's expressed opinion is his/her authentic opinion or the result of instructions and pressure from adults, or whether the child's expressed opinion or desire is in accordance with his/her best interests, shall be provided by experts. The Family Law prescribes the rule that a person selected by the child him/herself should be present at an interview with the child (Article 65, paragraph 6), but not how, on whose proposal and with whose help the child would choose this person to assist and support him/her in the proceedings in which he/she should form and express his/her opinion. Also undefined is the position of that person in relation to the collision guardian or temporary representative, who also have certain legal duties regarding the exercise of the childss right to express an opinion.

The obligation to obtain opinion from the child during court proceedings is not unconditional. The law imposes certain restrictions, and they are related to the assessment of the best interests of the child The court may deprive the child of the right to express an opinion in the proceedings whenever it considers that expressing an opinion would obviously be contrary to the best interests of the child (Family Law, Article 266 in fine), and no specific legal remedy is provided to ensure the control of the court decision brought without the child's involvement in the procedure (Delibašić, 2006, 28). The failure of the court to allow the child to express his/her opinion in the court proceedings concerning the child is not envisaged as a material breach of the provisions of the civil procedure which would lead to the annulment of the decision and which the second instance court would take into account ex officio (Petrušić, 2006b, 114), the so-called absolute material breach. Such a failure by the court could possibly be classified as the so-called relatively material breach, which exists when the court did not apply or incorrectly applied a procedural 
law provision during the proceedings, which was or could have influenced the issuance of a lawful and correct ruling, whereby such violations are only considered by the second instance court if the appellant has pointed to them.

\section{CONCLUSION}

The challenges of the modern judiciary faced with requests that should contribute to the idea that a child is informed on each and every proceeding in which issues related to the child are being decided, to be given the opportunity to form and express his/her own opinion, to participate in the proceedings in a manner adapted to his/her age and developmental capacities and to obtain his/her independent legal representative and all necessary legal assistance, better known as child-friendly justice standards, are based on the principles of a fair trial. The essential, constitutive elements of the right to a fair trial, in addition to the right of access to a court and legal remedy, are also the principles of equality of arms and fair balance. Neither party should be in a much weaker position in the proceedings than the other (Rozakis, 2004, pp. 96, 97). The principle of audiatur et altera pars primarily has a methodological value - the organization and manner of action of the court in litigation must be arranged in such a manner so as to enable the "other party" to be heard, which implies all of the parties involved in the dispute. However, in a lawsuit that discusses the relationship between the child and the parent, although the child has legal standing, he/she does not have the secured position of a party. He/she is usually not in the role of the plaintiff, but it is neither the "other" nor "opposing", nor should it be a "hidden" party. The child is and should be the central figure of the proceedings, because the proceedings are designed to protect him/her, to protect his/her rights. Therefore, the legal solutions according to which the child does not have to have the status of a party to the proceedings at all, and according to which both the court and the temporary representative of the child may decide that the child who is a party to the proceedings still does not receive all the information they might require to form and express their opinion on the subject matter of the proceedings, namely that they may arbitrarily decide that the child is not given the opportunity to participate in the proceedings at all in any way - because of their belief that it would harm his/her best interests, require serious review.

\section{REFERENCES}

Вујовић, Р. (2019). Лишење родитељьког права. [Deprivation of parental rights]. Београд: Службени гласник.

Вучковић Шаховић, Н., Петрушић, Н. (2015). Права детета. [Children rights]. Ниш: Правни факултет, Универзитет у Нишу.

Делибашић, 3. (2006). Права детета у спору за заштиту права детета и у спору за вршење односно лишење родитељског права [The rights of the child in the 
dispute for the protection of the child's rights and in the dispute for the exercise or deprivation of parental rights]. Билтен Окружног суда у Београду, број 74 (стр. 20-30), Београд.

Драшкић, М. (2005). Породично право и права детета. [Family Law and Child Rights] Београд: Службени гласник.

Dika, M. (2008). Građansko procesno pravo - Stranke i njihovi zastupnici i treći u parničnom postupku, IV knjiga. Zagreb: Narodne novine.

Ковачек-Станић, Г. (2005). Породично право. [Family law]. Нови Сад: Правни факултет Универзитета у Новом Саду.

Палачковић, Д. (2006). Процеси положаја детета под родитељским старањем у посебним парничним поступцима према новом Породичном закону Србије. [The processes of the position of the child under parental care in special civil proceedings under the new Family Law of Serbia]. У: Бејатовић, С. (ур.), Правни систем Србије и стандарди Европске уније и Савета Европе. Књ. 1. [The Serbian legal system and the standards of the European Union and the Council of Europe] (стр. 359-370). Крагујевац: Правни факултет, Институт за правне и друштвене науке.

Конвенције о правима детета. [Convention on the Rights of the Child]. Службени лист СФРЈ - Међународни уговори, број 15/90 и Службени лист СРЈ Међународни уговори, бр. 4/96 и 2/97.

Закон о парничном поступку. [Law on Civil Procedure]. Службени гласник PC, бр. 72/11, 49/13, 74/13 и 55/14.

Петрушић, Н. (2006а). Заступање детета у парници [Representing a child in a lawsuit]. У: Ђорђевић, М. (ур.). Правни живот бр. 10/2006 [Legal life No 10/2006] (169-191), Београд: Удружење правника Србије.

Петрушић, Н. (2006b). Право детета на слободно изражавање мишљења у новом породичном праву Републике Србије [The right of the child to freedom of expressionin the new family act of the Republic of Serbia]. У: Станковић, Г. (ур.). Новине у породичном законодавству [New developments in the Serbian family legislation] (99-117) Ниш: Правни факултет у Нишу, Центар за публикације.

Petrušić, N. (2016). Child-friendly legal aid in civil court proceedings: International standards and the circumstances in the Republic of Serbia. Facta Universitatis. Series Law and Politics. Vol. 14, No. 3 (pp. 395-407), Ниш: Универзитет у Нишу, Правни факултет.

Петрушић, Н. (2018). Процесна операционализација права детета на учешће у поступцима из породичних дноса у Породичном закону Србије: стање, изазови и перспективе [Process operationalization of children's rights for participation in family procedures according to family law of Serbia: current situation, challenges and perspectives]. У: Тркуља, Ј. (ур.), Тематски зборник радова Породични закон - дванаест година после [The serbian family act: 12 years later] (стр. 167-185). Београд: Правни факултет Универзитета Унион у Београду, Јавно предузеће Службени гласник.

Породични закон [Family law ]. Службени гласник PC, бр. 18/05, 72/11 и 6/15.

Poznić, B., Rakić-Vodinelić, V. (2015). Građansko procesno pravo, sedamnaesto izmenjeno i dopunjeno izdanje. [Civil procedural law]. Beograd: Pravni fakultet Univerziteta Union u Beogradu, Javno preduzeće Službeni glasnik.

Rozakis, C. (2004). The Right to a Fair Trial in Civil Cases, Judicial Studies Institute Journal, Vol. 4, No. 2 (pp. 96-106), Dublin: Judicial StudiesInstitute.

Rosenberg, L. (1954) Lehrbuch des deutschen Zivilprozessordnung, 6th. E4d. Munchen: Verlag, C.H. Beck.

Станковић, Г. (2012). Дете као странка у парничном поступку [Child as a party to litigation], У: Марковић, Г. (ур.) Зборник радова Права дјетета $u$ 
равноправност полова - између нормативног и стварног [Children's rights and gender equality - between normative and real] (стр. 29-46). Источно Сарајево: Правни факултет.

Станковић, Г. (2009). Ванпарнични поступак за стицање пословне способности [Out-of-court procedure for acquiring legal capacity], Билтен судске праксе, број 31 (стр. 115-133). Ниш: Окружни суд у Нишу, Intermex.

Станковић, О., Водинелић, В. (1996), Увод у грађанско право [Introduction to Civil Law]. Београд: Номос.

hорац, С. (2014). Право детета на изражавање мишљења у судском поступку [The right of the child to express an opinion in court proceedings]. У: Зборник радова Правног факултета у Нишу, број 66 [Proceedings of the Faculty of Law in Niš, No 66] (стр. 325-342). Ниш: Универзитет у Нишу, Правни факултет.

\title{
ПОЛОЖАЈ ДЕТЕТА У СУДСКОМ ПАРНИЧНОМ ПОСТУПКУ У ПРАВНИМ СТВАРИМА ВРШЕЊА, ЛИШЕЊА И ВРАЋАЊА РОДИТЕЉСКОГ ПРАВА
}

\author{
Ранка Вујовић \\ Републички секретаријат за законодавство, Београд, Србија
}

\section{Резиме}

У парницама за вршење, лишење и враћање родитељског права суделовања свих учесника односа у вези са којим је дошло до спора - односа детета и родитеља - од непроцењиве је важности за правилно и потпуно утврђивање чињеничног стања и доношење законите одлуке која ће у највећој мери задовољити најбоље интересе детета. Иако је у правним стварима вршења, лишења и враћања родитељског права детету законом признато право на тужбу, оно је само потенцијални, али не и нужни, учесник у судском поступку. Стварна легитимација припада родитељима, независно од легитимације детета, због чега дете углавном није у улози странке, а не постоји посебно процесно правило о нужном и јединственом супарничарству свих учесника спорног породичног односа. Процесне одредбе (опште и посебне) које омогућавају детету да када није подносилац тужбе, а није ни тужени, учествује у поступку у некој другој процесној улози - као умешач, сведок или само као неко ко има право да изрази своје мишљење о предмету поступка који га се тиче - тешко су спроводиве у пракси. Разлог за то није само неприлагођеност општих процесних правила стварним (развојним) способностима детета већ и недостатност посебних правила о заступању широко постављених дискреционих овлашћења привременог заступника и суда у процени да ли би учешће детета у конкретној парници било очигледно у супротности са његовим најбољим интересима, те низа других ограничавајућих правила и правних празнина. Дете које није ни странка ни умешач нема могућност улагања жалбе на судске одлуке којима је незадовољно, па и када је у самом поступку било у прилици да изрази своје мишљење у вези са предметом одлучивања. Све наведено објективно компромитује могућност учешћа детета у парницама у којима се одлучује о важним статусним питањима, питањима правног положаја, односно уређења правних односа детета и родитеља. 